\title{
Correction to: Supporting the classifcation of patients in public hospitals in Chile by designing, deploying and validating a system based on natural language processing
}

Fabián Villena ${ }^{1,2}$, Jorge Pérez ${ }^{3,4}$, René Lagos ${ }^{5}$ and Jocelyn Dunstan ${ }^{1,2^{*}}$ (1)

\section{Correction to: BMC Med Inform Decis Mak 21:208 (2021) https://doi.org/10.1186/s12911-021-01565- \\ $\mathbf{z}$}

Following publication of the original article [1], it was reported that the list of authors was published in the incorrect order. Jocelyn Dunstan was erroneously listed as the first author instead of the last. The authorship order has been amended and the original article has been updated. based on natural language processing. BMC Med Inform Decis Mak. 2021;21:208. https://doi.org/10.1186/s12911-021-01565-z.

\section{Publisher's Note}

Springer Nature remains neutral with regard to jurisdictional claims in published maps and institutional affiliations.

\begin{abstract}
Author details
${ }^{1}$ Center for Mathematical Modeling - CNRS UMI2807, Faculty of Physical and Mathematical Sciences, University of Chile, Santiago, Chile. ${ }^{2}$ Center for Medical Informatics and Telemedicine, ICBM, Faculty of Medicine, University of Chile, Santiago, Chile. ${ }^{3}$ Computer Science Department, Faculty of Physical and Mathematical Sciences, University of Chile, Santiago, Chile. ${ }^{4}$ Millennium Institute for Foundational Research on Data, Santiago, Chile. ${ }^{5}$ Digital Health Unit, South East Metropolitan Health Service, Santiago, Chile.
\end{abstract}

Published online: 20 July 2021

\author{
Reference \\ 1. Villena F, Pérez J, Lagos R, et al. Supporting the classification of patients in \\ public hospitals in Chile by designing, deploying and validating a system
}

The original article can be found online at https://doi.org/10.1186/s12911021-01565-z

${ }^{1}$ Center for Mathematical Modeling - CNRS UMI2807, Faculty of Physical and Mathematical Sciences, University of Chile, Santiago, Chile

Full list of author information is available at the end of the article

(c) The Author(s) 2021. Open Access This article is licensed under a Creative Commons Attribution 4.0 International License, which permits use, sharing, adaptation, distribution and reproduction in any medium or format, as long as you give appropriate credit to the original author(s) and the source, provide a link to the Creative Commons licence, and indicate if changes were made. The images or other third party material in this article are included in the article's Creative Commons licence, unless indicated otherwise in a credit line to the material. If material is not included in the article's Creative Commons licence and your intended use is not permitted by statutory regulation or exceeds the permitted use, you will need to obtain permission directly from the copyright holder. To view a copy of this licence, visit http://creativecommons.org/licenses/by/4.0/. The Creative Commons Public Domain Dedication waiver (http://creativeco mmons.org/publicdomain/zero/1.0/) applies to the data made available in this article, unless otherwise stated in a credit line to the data. 